J-SANAK: Jurnal Kajian Anak

(p-ISSN: 2686-5343 le-ISSN: 2715-7989)

Vol. (2)(02), (Januari-Juni)(2021), (Halaman)(60-75)

DOI: https://doi.org/10.24127/j-sanak.v2i02.817

\title{
PENINGKATAN KETERAMPILAN BERBICARA MELALUI METODE BERCERITA DENGAN MEDIA BONEKA KAUS KAKI
}

\author{
Umi Salamah ${ }^{1}$ \\ Sekolah Tinggi Keguruan dan Ilmu Pendidikan Bina Insan Mandiri Surabaya \\ umisalamah1767@gmail.com \\ Indaria Tri Hariyani ${ }^{2}$ \\ Sekolah Tinggi Keguruan dan Ilmu Pendidikan Bina Insan Mandiri Surabaya \\ indahariyani442@gmail.com \\ Norma Diana Fitri ${ }^{3}$ \\ Sekolah Tinggi Keguruan dan Ilmu Pendidikan Bina Insan Mandiri Surabaya \\ normadiana79@gmail.com
}

\begin{abstract}
ABSTRAK
Berdasarkan pada hasil obeservasi di Taman Kanak-kanak Banyu Urip, perkembangan keterampilan berbicara anak pada kelompok B belum berkembang secara optimal. Penelitian ini bertujuan untuk peningkatan keterampilan berbicara anak melalui metode bercerita dengan menggunakan media boneka kaus kaki pada kelompok B di TK Banyu Urip, Surabaya. Penelitian ini menggunakan metode penelitian tindakan kelas yang dilakukan dengan cara kolaborasi antara peneliti dengan guru. Subjek yang diteliti adalah siswa Kelompok B di TK Banyu Urip, Surabaya. Jumlah sampel penelitian ini berjumlah 27 anak. Instrumen penelitian yang digunakan dalam penelitian ini adalah kisi-kisi lembar observasi (checklist). Teknik analisis data menggunakan teknik analisis deskriptif kuantitatif dan kualitatif. Hasil penelitian menunjukkan adanya peningkatan keterampilan berbicara pada anak melalui metode bercerita dengan media boneka kaus kaki. Hasil observasi pada tahap pratindakan menunjukkan keterampilan berbicara pada anak sebesar 56\% dengan kriteria baik. Pada siklus I mengalami peningkatan dengan persetase $67 \%$ hasil ini menunjukkan peningkatan sebesar $11 \%$. Pada siklus II mengalami peningkatan dengan persentase $80 \%$ hasil ini menunjukkan peningkatan sebesar $13 \%$. Berdasarkan hasil tersebut dapat disimpulkan bahwa metode bercerita dengan media boneka kaus kaki dapat meningkatkan keterampilan berbicara pada siswa kelompok B di TK Banyu Urip, Surabaya.
\end{abstract}

Kata Kunci: Keterampilan Berbicara; Metode Bercerita; Media Boneka Kaus Kaki Received 28-04-2021; Received in revised form 24-05-2021; Accepted 03-07-2021. 
J-SANAK: Jurnal Kajian Anak

(p-ISSN: 2686-5343 le-ISSN: 2715-7989)

Vol. (2)(02), (Januari-Juni)(2021), (Halaman)(60-75)

DOI: https://doi.org/10.24127/j-sanak.v2i02.817

\begin{abstract}
Based on the result of observations at Banyu Urip Kindergarten, the development of children's speaking skills in group B has not developed optimally. This research aims to improve children's speaking skills through a storytelling method using socks puppet media in group B in Banyu Urip, Surabaya. This research used the method of classroom action research conducted by collaboration between researcher and teachers. The subjects studied were students of Group B at TK Banyu Urip, Surabaya. The number of samples in this study may be 27 children. The reseach instrument used in this study was the observasion sheet grid (checklist). The data analysis technique used quantitative and qualitative analiysis techniques. The results of the observation at the pre-action stage showed that the speaking skills of children were $56 \%$ with good criteria. In the first cycle there was an increase of $67 \%$, this result showed an increase of $11 \%$. In the second cycle there was an increase of $80 \%$, this result showed an increase of $13 \%$. Based on these results it can be denied that storytelling method using sock puppet media can improve speaking skills in group B student in Banyu Urip Kindergarten, Surabaya.
\end{abstract}

\title{
Keywords: Speaking Skills; Storytelling Method; Socks Puppet
}

\section{A. PENDAhuluan}

Masa Golden age akan terjadi pada anak saat usia 0 - 6 tahun. Pada saat anak memasuki usia empat hingga enam (4 - 6) tahun, anak akan mulai sensitif dalam hal menerima berbagai upaya yang tengah dilakukan untuk pertumbuhan dan perkembangannya, dan anak akan siap merespon rangsangan atau stimulus yang diberikan oleh lingkungan. Orang tua dan pendidik hendaknya memberikan stimulus yang sesuai dengan yang dibutuhkan sang anak dan juga orang tua diwajibkan untuk selalu memantau tumbuh kembang anak, supaya gangguan dan hambatan dapat segera terdeteksi, dengan begitu pertumbuhan dan perkembangan anak dapat tercapai secara optimal. Tingkat pencapaian perkembangan bahasa atau keterampilan berbicara yang harus dimiliki oleh anak dalam usia 5-6 tahun menurut Standar Tingkat Pencapaian Perkembangan Anak (STPPA) yaitu menjawab pertanyaan yang lebih kompleks, menyebutkan kelompok gambar yang memiliki bunyi yang sama, memiliki perbendaharaan kata untuk berkomunikasi secara lisan, mengenal berbagai macam simbol-simbol, menyusun kalimat sederhana dalam struktur lengkap, memiliki lebih banyak kata-kata untuk mengepresikan idenya kepada orang lain, 
J-SANAK: Jurnal Kajian Anak

(p-ISSN: 2686-5343 le-ISSN: 2715-7989)

Vol. (2)(02), (Januari-Juni)(2021), (Halaman)(60-75)

DOI: https://doi.org/10.24127/j-sanak.v2i02.817

melanjutkan sebagian cerita yang telah ia dengar, menunjukkan pemahaman konsepkonsep dalam buku cerita.

Berdasarkan pada hasil obeservasi di Taman Kanak-kanak Banyu Urip, perkembangan keterampilan berbicara anak pada kelompok B belum berkembang secara optimal. Hal ini dapat dilihat yaitu anak yang sudah memiliki keterampilan berbicara dalam kategori "sangat baik" yaitu hanya ada 3 anak dari jumlah murid 27 anak pada kelompok B atau dengan persentase 11\%, dan anak dalam kategori yang masih perlu dilakukan peningkatan yaitu ada 24 anak atau dengan persentase $89 \%$. Kondisi tersebut dapat dilihat ketika anak diminta untuk menceritakan pengalaman atau kejadian didepan kelas, untuk sebagian anak tersebut tidak mampu menceritakan pengalaman/kejadian secara urut, runtut dan jelas. Selain itu anak juga belum mampu untuk menjawab pertanyaan dan menceritakan kembali isi cerita yang telah disampaikan oleh pendidik atau guru.

Mengembangkan keterampilan berbicara akan kurang sempurna jika hanya mengandalkan keaktifan guru atau teacher centered. Untuk mengoptimalkan perkembangan keterampilan berbicara anak, maka anak harus terlibat aktif dalam kegiatan pembelajaran tersebut. Sejalan dengan yang diungkapkan oleh (Moeslichatoen, 2004) metode bercerita merupakan salah satu diantara banyaknya metode yang digunakan untuk memberikan pengalaman belajar bagi anak. Maka salah satu media yang tepat untuk media pemebelajaran anak usia dini adalah boneka kaus kaki. kelebihan menggunakan media boneka kaus kaki sebagai media pembelajaran adalah sebagai berikut : 1) Efisien terhadap waktu, tempat, biaya, dan persiapan; 2) Tidak memerlukan keterampilan yang rumit; 3). Dapat mengembangkan imajinasi dan aktivitas anak dalam suasana gembira. Boneka adalah benda tiruan dari bentuk manusia atau binatang, dan lain sebagainya (Daryanto, 2013). Boneka menjadi alat peraga yang dianggap mendekati naturalitas bercerita. Tokoh-tokoh yang diwujudkan melalui boneka berbicara dengan gerakan-gerakan yang mendukung cerita dan mudah diikuti anak. Melalui boneka anak tahu tokoh mana yang sedang berbicara, apa isi pembicaraannya, dan bagaimana pelakunya. Media boneka merupakan media yang disajikan secara prolog atau dialog dengan peserta didik. Dengan menggunakan media mampu memberikan pendidikan dan hiburan yang menarik bagi peserta didik sehingga anak menjadi lebih komunikatif. Dengan adanya media peserta didik tetap dapat mengungkapkan pikiran, ide atau gagasan secara lisan. Media yang dapat digunakan dalam proses pembelajaran yaitu boneka, papan flanel, gambar bergerak, buku, dan gambar berseri. Dengan pemilihan dan penggunaan media yang tepat, peserta didik akan lebih leluasa dalam pengembangan keterampilan berbicaranya.

Copyright (@ 2020, Universitas Muhammadiyah Metro| 62 
J-SANAK: Jurnal Kajian Anak

(p-ISSN: 2686-5343 e-ISSN: 2715-7989)

Vol. (2)(02), (Januari-Juni)(2021), (Halaman)(60-75)

DOI: https://doi.org/10.24127/j-sanak.v2i02.817

Berdasarkan penjelasan dan hasil observasi di atas, maka peneliti bermaksud untuk melakukan sebuah Penelitian Tindakan Kelas (PTK) dengan judul "Upaya Peningkatan Keterampilan Berbicara Melalui Metode Bercerita Dengan Media Boneka Kaus Kaki pada kelompok B di TK Banyu Urip, Kecamatan Sawahan, Kota Surabaya". Melalui penelitian tersebut diharapkan keterampilan berbicara anak dapat ditingkatkan melalui metode bercerita dengan menggunakan media boneka kaus kaki.

\section{B. METODOLOGI}

Peneliti dalam melaksanakan penelitian ini menggunakan model penelitian dari Kemmis dan Taggart yang terdiri atas tahapan-tahapan perencanaan, pelaksanaan/tindakan, observasi, refleksi. Apabila dalam satu siklus kegiatan belum berhasil untuk mengembangkan keterampilan berbicara anak, maka kegiatan penelitian akan dilanjutkan pada siklus berikutnya dengan memberikan perbedaan tindakan atau perlakuan pada siklus selanjutnya. Keempat tahapan ini akan membentuk siklus.

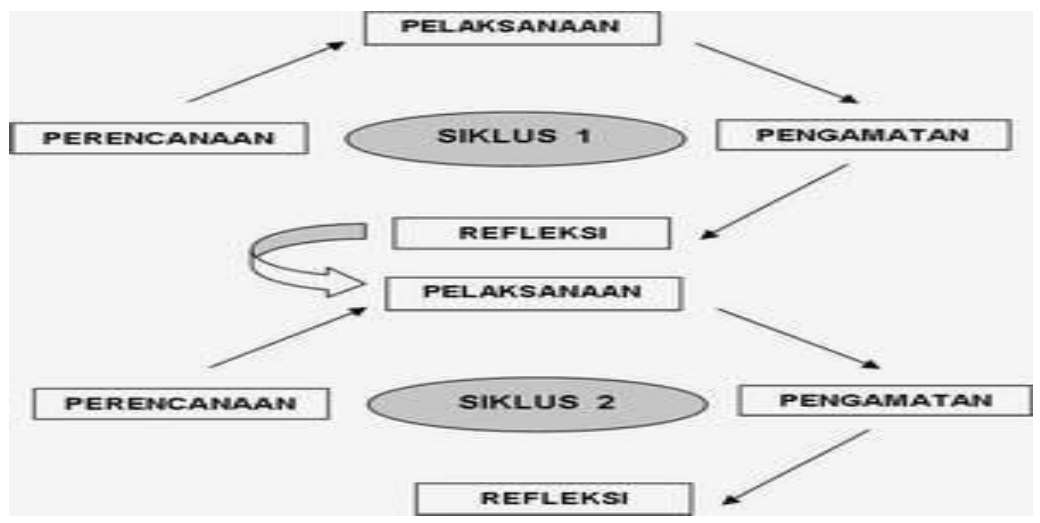

Gambar 1.Model Penelitian Tindakan Kelas dari Kemmis \& Mc. Taggart (Arikunto, 2010)

\section{Lokasi Penelitian}

Penelitian Tindakan Kelas ini dilakukan di TK Banyu Urip yang beralamat di Jl. Banyu Urip Kidul I No. 1 C, Kecamatan Sawahan, Kabupaten Kota Surabaya. Pemilihan penelitian di TK Banyu Urip karena masih memiliki masalah dalam pengembangan berbahasa yaitu keterampilan berbicara. 
J-SANAK: Jurnal Kajian Anak

(p-ISSN: 2686-5343 le-ISSN: 2715-7989)

Vol. (2)(02), (Januari-Juni)(2021), (Halaman)(60-75)

DOI: https://doi.org/10.24127/j-sanak.v2i02.817

\section{Populasi Penelitian}

Berdasarkan pendapat di atas, maka pada penelitian ini jumlah populasi yang digunakan yaitu seluruh anak kelompok B1 yang ada di TK Banyu Urip, yang berjumlah 27 anak.

\section{Instrumen Pengumpulan Data}

Instrumen penelitian untuk pengumpulan data pada penelitian ini berbentuk check list, yang merupakan pedoman observasi yang berisikan daftar dari semua aspek yang akan diobservasi, sehingga observer tinggal memberi tanda centang $(\sqrt{ })$ pada aspek yang diobservasi, check list merupakan alat observasi yang praktis untuk digunakan, sebab semua aspek yang akan diteliti sudah ditentukan terlebih dahulu. Kisi-kisi lembar observasi (check list) keterampilan berbicara anak selanjutnya dituangkan dalam rubrik untuk mempermudah penilaian. Adapun lembar observasi yang digunakan adalah sebagai berikut:

\section{Teknik Pengumpulan Data}

Teknik pengumpulan data dalam penelitian tindakan kelas adalah catatan lapangan (observasi) dan dokumentasi.

1. Wawancara

Pada penelitian ini, peneliti melakukan kegiatan tanya jawab secara langsung dengan narasumber, yaitu pendidik atau guru.

2. Observasi

Data-data yang diambil dalam penelitian ini mengenai keterampilan berbicara melalui metode bercerita dengan media boneka kaus kaki pada kelompok B. Proses pengamatan atau observasi dilakukan oleh peneliti dengan mengamati satu demi satu anak ketika guru melaksanakan tindakan.

3. Dokumentasi

Hasil penelitian-penelitian akan lebih terpercaya dengan didukung oleh beberapa dokumentasi. Pada penelitian ini, dokumentasi dilakukan dengan cara mengambil foto anak dan arsip-arsip lain pada saat kegiatan pembelajaran dalam meningkatkan keterampilan berbicara melalui metode bercerita dengan media boneka kaus kaki itu berlangsung. Foto-foto digunakan untuk merekam kegiatan-kegiatan atau keaktifan setiap anak selama kegiatan. 
J-SANAK: Jurnal Kajian Anak

(p-ISSN: 2686-5343 le-ISSN: 2715-7989)

Vol. (2)(02), (Januari-Juni)(2021), (Halaman)(60-75)

DOI: https://doi.org/10.24127/j-sanak.v2i02.817

\section{Teknik Analisis Data}

Dalam penelitian ini, analisis data dilakukan dengan analisis deskriptif kualitatif dan kuantitatif. Deskripsi kuantitatif digunakan untuk menganalisis data berupa angka. Deskripsi kualitatif ditujukan untuk menggambarkan hasil pengamatan peneliti tentang kemampuan melanjutkan sebagian cerita/dongeng yang telah diperdengarkan; mendengarkan cerita dengan sungguh-sungguh; menjawab pertanyaan yang lebih kompleks; dapat mengucapkan lebih dari tiga kalimat; kesediaan menghargai pembicaraan maupun gagasan orang lain; kenyaringan suara dan kelancaran dalam berbicara. Hasil pengamatan dihitung kemudian dipersentasekan. Cara pemerolehan data menurut Acep Yoni (2010: 177) adalah:

$$
\text { Persentase }=\frac{\text { skor keseluruhan yang diperoleh anak }}{\text { Jumlah anak x Skor Umum }} \times 100 \%
$$

\section{HASIL DAN PEMBAHASAN}

\section{Hasil}

\section{Deskripsi Hasil Tindakan Siklus I}

Adapun tahap perencanaan pada siklus I meliputi kegiatan sebagai berikut:

a. Melakukan koordinasi dengan guru sebagai kolaborator

b. Menyusun RKH (Rencana Kegiatan Harian) dengan tema alam semesta

c. Menyiapkan media boneka kaus kaki yang akan digunakan untuk bercerita.

d. Menyiapkan perlengkapan pembelajaran.

e. Menyiapakan instrumen pengamatan.

Pelaksanaan kegiatan pembelajaran dilaksanakan oleh guru, peneliti hanya sebagai pengamat dan penilai. Sebelum melaksanakan kegiatan pembelajaran guru melakukan apersepsi kemudian dilanjutkan dengan menjelaskan pembelajaran yang salah satu kegiatannya yaitu bercerita menggunakan media boneka kaus kaki.

Pelaksanaan tindakan Siklus I dilaksanakan sebanyak 3 kali pertemuan. Untuk pertemuan pertama dilakukan pada tanggal 12 Februari 2019, pertemuan kedua dilakukan pada tanggal 16 Februari 2019, dan pertemuan ketiga dilakukan pada tanggal 20 Februari 2019. Pelaksanaan penelitian dilaksanakan saat kegiatan pembelajaran berlangsung. Berikut deskripsi pelaksanaan kegiatan Siklus I:

a. Pelaksanaan Tindakan Siklus I Pertemuan Pertama

Pertemuan pertama dilaksanakan pada hari Selasa, 12 Februari 2019. Sebelum kegiatan bercerita dimulai, guru mengatur tempat duduk anak. Anak- 
J-SANAK: Jurnal Kajian Anak

(p-ISSN: 2686-5343 le-ISSN: 2715-7989)

Vol. (2)(02), (Januari-Juni)(2021), (Halaman)(60-75)

DOI: https://doi.org/10.24127/j-sanak.v2i02.817

anak duduk menghadap kepada guru untuk memudahkan agar anak dapat memperhatikan cerita yang disanpaikan oleh guru. Setelah anak siap dan duduk dengan baik, maka guru memulai berdoa bersama sebelum belajar. Setelah selesai berdoa, guru mengajak anak bertepuk tangan sesuai tema yang dikembangkan pada hari itu. Selanjutnya, guru memperkenalkan boneka kaus kaki yang akan digunakan sebagai alat peraga kegiatan bercerita.

Kegiatan inti yaitu guru membawakan sebuah cerita yang berjudul "Lingkungan Bersih, Badan Sehat" dengan menggunakan boneka kaus kaki yang telah disediakan. Pada kegiatan pembelajaran berlangsung beberapa anak terlihat antusias mendengarkan dan menyimak cerita, namun sebagian lagi masih asyik berbicara sendiri dan hanya sekali dua kali terlihat mendengarkan dan menyimak cerita yang disampaikan guru. Setelah kegiatan bercerita selesai, guru melakukan tanya jawab yang berkaitan dengan isi cerita yang telah dibawakan.

Pada pertemuan ini, belum semua anak mampu untuk menyampaikan maksud (ide, pikiran, gagasan dan perasaan) dengan lancar dan jelas, membuat kalimat sederhana dalam bahasa lisan dan struktur lengkap. Namun ada juga juga yang sudah mampu berkomunikasi dengan kalimat sederhana secara lancar dan jelas. Pada kegiatan tanya jawab pun anak sudah dapat menjawab pertanyaan dari guru. Namun masih ada sebagian anak yang perlu bantuan guru dalam menjawab pertanyaan.

\section{b. Pelaksanaan Tindakan Siklus I Pertemuan Kedua}

Pertemuan kedua pada Siklus Pertama ini dilaksanakan pada hari Sabtu, 16 Februari 2019. Pada pertemuan kedua, kegiatan yang dilakukan adalah anak diminta bercerita satu persatu di depan kelas dengan menggunakan boneka kaus kaki, dengan alur cerita yang telah dibuat oleh pendidik atau guru. Sebelum anak bercerita, guru menceritakan cerita yang akan disampaikan kepada anak. Cerita tersebut berjudul "Akibat Membuang Sampah Sembarangan".

Pada pertemuan ini, masih banyak sekali anak yang malu-malu untuk bercerita di depan kelas. Anak sudah sedikit mampu menyampaikan maksud namun belum mampu membuat kalimat sederhana. Masih banyak anak yang butuh bimbingan guru dan peneliti, tetapi banyak juga anak yang telah mengalami peningkatan.

c. Pelaksanaan Tindakan Siklus I Pertemuan Ketiga

Pertemuan ketiga pada Siklus I dilaksanakan pada hari Rabu, 20 Februari 2019. Pada pertemuan ketiga, guru meminta anak bercerita tentang pengalamannya satu persatu di depan kelas dengan menggunakan media boneka

Copyright $($ ) 2020, Universitas Muhammadiyah Metro| 66 
J-SANAK: Jurnal Kajian Anak

(p-ISSN: 2686-5343 le-ISSN: 2715-7989)

Vol. (2)(02), (Januari-Juni)(2021), (Halaman)(60-75)

DOI: https://doi.org/10.24127/j-sanak.v2i02.817

kaus kaki. Dari cerita yang dibawakan oleh anak, guru akan mengajukan pertanyaan untuk anak yang telah bercerita. Kegiatan tanya jawab antara guru dan anak bertujuan untuk menggali keterampilan berbicara anak.

Pada pertemuan ini, sebagian anak sudah cukup mampu bercerita di depan teman-temannya. Hanya saja masih belum sempurna menyusun kalimat sederhananya. Anak sering memasukkan bahasa jawa pada tiap kalimat yang anak ucapkan. Kemudian guru membenarkan kata-kata yang salah. Keterampilan berbicara anak sudah sedikit membaik dari pertemuan sebelumnya dan sebagian anak sudah mulai sedikit berani tanpa harus malumalu lagi.

\section{Hasil Observasi Siklus 1}

Pengamatan observasi pada Siklus 1 dilakukan oleh peneliti dengan bantuan guru. Pada setiap pertemuan peneliti mencatat, mendokumentasikan, mengamati, dan menilai semua kegiatan yang dilakukan oleh siswa dengan tujuan untuk memastikan bahwa semua telah berjalan dengan baik, dan sesuai dengan apa yang telah direncanakan. Pada observasi ini, yang menjadi indikator untuk diamati dan dinilai dari anak adalah anak dapat berbicara lancar dengan kalimat sederhana dan dipahami orang lain, anak dapat menjawab pertanyaan (apa, siapa, kapan, mengapa, dimana), anak dapat menceritakan kembali cerita yang telah dibawakan oleh guru.

Kegiatan pembelajaran pada Siklus I yang dilaksanakan selama 3 kali pertemuan telah berjalan dengan baik. Setelah beberapa hari dilaksanakan kegiatan pembelajaran bercerita dengan menggunakan media boneka kaus kaki, anak sedikit demi sedikit mulai menyesuaikan diri dengan baik pada metode pembelajaran tersebut. Anak-anak sangat antusias dan sangat bersemangat ketika pelaksanaan kegiatan bercerita akan dimulai.

Pada pelaksanaan tindakan Siklus I dari pertemuan pertama, kedua, dan ketiga memberikan gambaran bahwa terjadi peningkatan keterampilan berbicara pada anak kelompok B di TK Banyu Urip. Meskipun demikian, masih ada beberapa anak yang keterampilan berbicaranya belum bisa dikatakan ada peningkatan, oleh karena itu baik peneliti maupun guru harus tetap memberikan motivasi dan stimulus kepada anak-anak tersebut, karena anak tersebut hanya mampu berbicara sepatah-sepatah saja, serta beberapa siswa belum terlibat secara aktif dalam kegiatan bercerita menggunakan media boneka kaus kaki. 
J-SANAK: Jurnal Kajian Anak

(p-ISSN: 2686-5343 le-ISSN: 2715-7989)

Vol. (2)(02), (Januari-Juni)(2021), (Halaman)(60-75)

DOI: https://doi.org/10.24127/j-sanak.v2i02.817

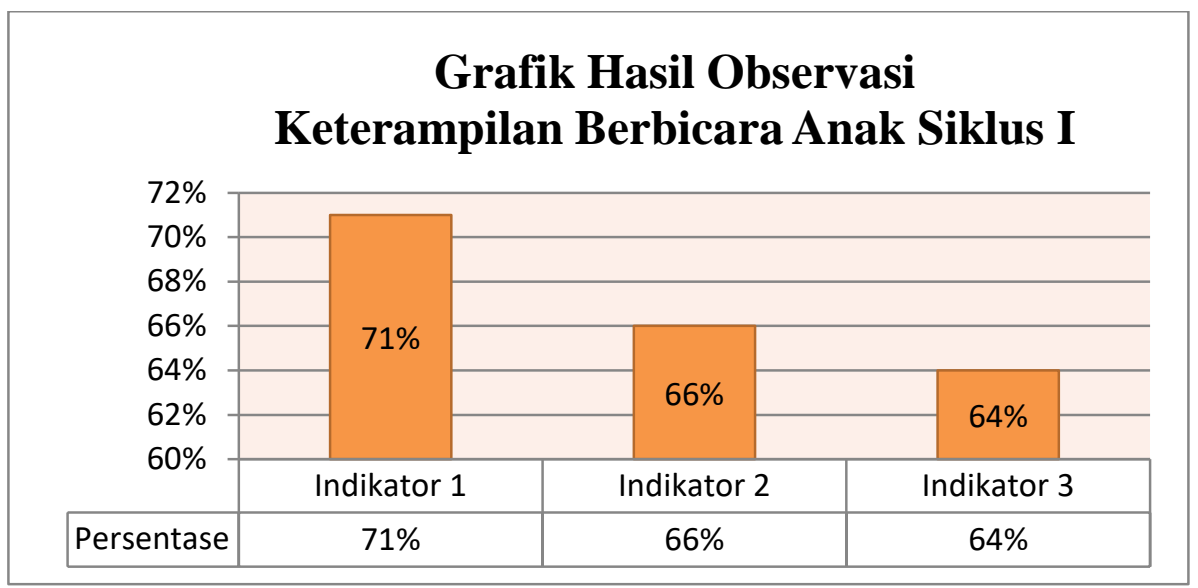

Grafik 1. Hasil Observasi Keterampilan Berbicara Anak Siklus I

Berdasarkan hasil observasi keterampilan berbicara pada anak kelompok B di TK Banyu Urip melalui tindakan kelas Siklus I dapat diketahui bahwa hasil rata-rata pencapaian keterampilan berbicara anak pada Siklus I sebesar 67\%. Sehingga dapat disimpulkan bahwa keterampilan berbicara anak ada peningkatan apabila dibandingkan dengan keterampilan berbicara sebelum tindakan kelas (pra tindakan). Peningkatan tersebut $11 \%$ lebih besar jika dibanding dengan pratindakan yang semula dengan persentase $56 \%$.

\section{Refleksi}

Setelah pelaksanaan Siklus I yang dilaksanakan guna peningkatan keterampilan berbicara pada anak kelompok B di TK Banyu Urip, maka langkah selanjutnya adalah melakukan refleksi. Refleksi pada Siklus I ini dilakukan untuk mengevaluasi kegiatan yang telah dilakukan dan menemukan masalah-masalah yang kemudian akan dikembangkan. Berikut kendala-kendala yang dapat ditemukan pada siklus I:

a. Beberapa anak masih belum mampu mengungkapkan pendapatnya, dalam menceritakan kembali isi cerita anak belum lancar, belum urut dan juga tidak percaya diri sehingga anak masih membutuhkan motivasi dan bimbingan dari guru.

b. Ketika sesi tanya jawab guru mengalami kesulitan mengatur anak supaya tidak ramai pada saat pembelajaran.

c. Pada saat anak maju ke depan untuk menceritakan kembali isi cerita, sebagian anak belum berani. Hal ini disebabkan karena anak belum percaya diri untuk maju ke depan.

d. Tidak ada penghargaan yang konkret sehingga belum membuat anak termotivasi untuk bercerita. 
J-SANAK: Jurnal Kajian Anak

(p-ISSN: 2686-5343 le-ISSN: 2715-7989)

Vol. (2)(02), (Januari-Juni)(2021), (Halaman)(60-75)

DOI: https://doi.org/10.24127/j-sanak.v2i02.817

Adapun perbaikan yang harus dilakukan dalam pelaksanaan Siklus I adalah sebagai berikut:

a. Pemberian motivasi kepada anak yang masih belum aktif atau masih belum percaya diri dalam bercerita dan terlibat diskusi serta tanya jawab selama kegiatan bercerita disertai boneka kaus kaki berlangsung.

b. Guru membuat kelompok menjadi tiga anak pada setiap kelompok untuk maju secara bergantian melakukan kegiatan bercerita dengan menggunakan media boneka kaus kaki dengan alur cerita yang telah disiapkan oleh guru.

c. Memberikan penghargaan yang semula hanya bintang yang ditulis dipapan tulis diganti dengan memberikan penghargaan berupa coklat sebagai apresiasi terhadap keterampilan berbicara anak.

Berdasarkan pada hasil observasi dan refleksi pada siklus I, dan jumlah skor dan persentase yang diperoleh oleh anak telah mulai ada peningkatan, meskipun masih ada beberapa anak yang keterampilan berbicaranya masih kurang, maka siklus ini akan dilanjutkan ke siklus II.

\section{Deskripsi Hasil Tindakan Siklus II}

\section{Perencanaan Tindakan Siklus II}

Adapun tahap perencanaan pada siklus II meliputi kegiatan sebagai berikut:

a. Melakukan koordinasi dengan guru sebagai kolaborator

b. Menyusun RKH (Rencana Kegiatan Harian) dengan tema alam semesta

c. Menyiapakan media boneka kaus kaki yang akan digunakan untuk bercerita.

d. Menyiapkan perlengkapan pembelajaran.

e. Menyiapakan instrumen pengamatan.

\section{Pelaksanaan Tindakan Siklus II}

Pelaksanaan tindakan Siklus II dilakukan selama tiga kali pertemuan. Adapun jadwal pelaksanaan Siklus II yaitu Pertemuan Pertama hari Sabtu, 2 Maret 2019, Pertemuan Kedua hari Sabtu, 9 Maret 2019 dan Pertemuan Ketiga hari Selasa, 12 Maret 2019. Pelaksanaan penelitian dilakukan saat kegiatan pembelajaran berlangsung, yaitu pada pukul 08.00-11.00 WIB dan sudah tercantum dalam RKH sehingga pelaksanaannya dapat berjalan dengan baik. Tema pembelajaran yang dikembangkan adalah Alam Semesta.

a. Pelaksanaan Tindakan Siklus II Pertemuan Pertama

Pertemuan pertama Pada Siklus II dilaksanakan pada hari Sabtu, 02 Maret 2019. Kegiatan awal sebelum pembelajaran guru mengucap salam, dilanjutkan 
J-SANAK: Jurnal Kajian Anak

(p-ISSN: 2686-5343 le-ISSN: 2715-7989)

Vol. (2)(02), (Januari-Juni)(2021), (Halaman)(60-75)

DOI: https://doi.org/10.24127/j-sanak.v2i02.817

dengan berdoa, kemudian dilanjutkan dengan apersepsi mengenai sub tema pada hari itu yaitu tanya jawab dan diskusi mengenai alam semesta.

Kegiatan inti, guru membawakan sebuah cerita yang berjudul "Suka Membantu Ibu" dengan menggunakan media boneka kaus kaki yang telah disediakan. Kemudian guru membentuk kelompok yang terdiri dari 3 anak. Pembagian kelompok ditujukan agar anak dapat berinteraksi dengan temantemannya, melatih lebih efektif lagi keterampilan berbicara anak. Tiap kelompok diminta untuk maju di depan kelas untuk kegiatan bercerita menggunakan media boneka kaus kaki. Setiap kelompok yang maju akan diberi pertanyaan oleh guru untuk masing-masing anak. Kegiatan tanya jawab antara guru dan anak bertujuan untuk menggali tentang keterampilan berbicara anak.

Pada pertemuan ini, masih terdapat anak yang pendiam dan masih memerlukan ajakan dari guru untuk berinteraksi. Kelompok yang maju di depan kelas pun ketika bercerita hanya satu atau dua anak yang berbicara dari jumlah 3 anak dari masing-masing kelompok. Juga masih terdapat beberapa anak yang masih bingung untuk menjawab suatu pertanyaan dari guru.

b. Pelaksanaan Tindakan Siklus II Pertemuan Kedua

Pertemuan kedua pada Siklus II dilaksanakan pada hari Sabtu, 09 Maret 2019. Kegiatan awal sebelum pembelajaran guru mengucap salam, dilanjutkan dengan berdoa, kemudian dilanjutkan dengan apersepsi mengenai sub tema pada hari itu yaitu tanya jawab dan diskusi mengenai alam semesta.

Kegiatan inti, guru kembali membawakan sebuah cerita yang berjudul "Aku Suka Kota Ku Bersih" dengan menggunakan media boneka kaus kaki. Kemudian guru membentuk kelompok yang terdiri dari 3 anak. Pembagian kelompok ditujukan agar anak dapat berinteraksi dengan teman-temannya, melatih lebih efektif lagi keterampilan berbicara anak. Tiap kelompok diminta untuk maju di depan kelas untuk kegiatan bercerita menggunakan media boneka kaus kaki. Setiap kelompok yang maju akan diberi pertanyaan oleh guru untuk masing-masing anak. Kegiatan tanya jawab antara guru dan anak bertujuan untuk menggali tentang keterampilan berbicara anak.

Pada pertemuan ini, sebagian besar anak-anak sudah ikut aktif terlibat dalam kegiatan pembelajaran. Pada kegiatan tanya jawab pun, anak mampu menjawab pertanyaan guru dengan cukup baik. Beberapa diantaranya sudah bisa bercerita secara urut dan jelas tentang apa yang mereka ketahui dan mereka dengar.

c. Pelaksanaan Tindakan Siklus II Pertemuan Ketiga

Pertemuan ketiga pada Siklus II dilaksanakan pada hari Selasa, 12 Maret 2019. Kegiatan awal sebelum pembelajaran guru mengucap salam, dilanjutkan 
J-SANAK: Jurnal Kajian Anak

(p-ISSN: 2686-5343 e-ISSN: 2715-7989)

Vol. (2)(02), (Januari-Juni)(2021), (Halaman)(60-75)

DOI: https://doi.org/10.24127/j-sanak.v2i02.817

dengan berdoa, kemudian dilanjutkan dengan apersepsi mengenai sub tema pada hari itu yaitu tanya jawab dan diskusi mengenai gejala alam yang belum diketahui anak.

Kegiatan inti, guru kembali membawakan sebuah cerita yang berjudul "Temanku Sakit" dengan menggunakan media boneka kaus kaki yang telah disediakan. Guru kembali membentuk kelompok yang terdiri dari 3 anak, hanya saja dengan anggota yang berbeda. Hal ini bertujuan agar anak tidak hanya terampil berbicara dengan satu teman saja namun seluruh yang ada di kelas. Tiap kelompok diminta maju ke depan untuk bercerita menggunakan media boneka kaus kaki dengan alur cerita yang telah disampaikan guru. Setelah itu guru kembali memberikan pertanyaan-pertanyaan yang berkaitan dengan cerita yang telah dibawakan. Setelah anak selesai maju, guru memberikan penghargaan bintang dan coklat sebagai bentuk apresiasi atas antusiasnya anakanak dalam kegiatan bercerita menggunakan media boneka kaus kaki dalam rangka meningkatkan keterampilan berbicara.

Pada pertemuan ini, Anak sudah dapat mengungkapkan ide, pikiran, gagasan, dan perasaan serta sudah mampu menyusun kalimat sederhana secara struktur. Rata-rata anak sudah menggunakan 5-6 kata dalam setiap kalimatnya. Sebagian besar anak-anak sudah mampu bercerita secara urut, jelas dan sesuai dengan kreativitasnya. Anak menjawab pertanyaan guru juga sudah sangat baik.

\section{Hasil Observasi Siklus II}

Seperti halnya pada Siklus I, observasi pada Siklus II juga dilaksanakan ketika kegiatan pembelajaran berlangsung dengan menggunakan lembar observasi yang telah disiapkan. Pada observasi ini, yang menjadi indikator untuk diamati dan dinilai dari anak adalah anak dapat berbicara lancar dengan kalimat sederhana dan dipahami orang lain, anak dapat menjawab pertanyaan (apa, siapa, kapan, mengapa, dimana), anak dapat menceritakan kembali cerita yang telah dibawakan oleh guru.

Hasil observasi yang diperoleh dari tindakan Siklus II mengalami peningkatan yang signifikan. Berikut grafik pencapaian keterampilan berbicara siklus II: 
J-SANAK: Jurnal Kajian Anak

(p-ISSN: 2686-5343 le-ISSN: 2715-7989)

Vol. (2)(02), (Januari-Juni)(2021), (Halaman)(60-75)

DOI: https://doi.org/10.24127/j-sanak.v2i02.817

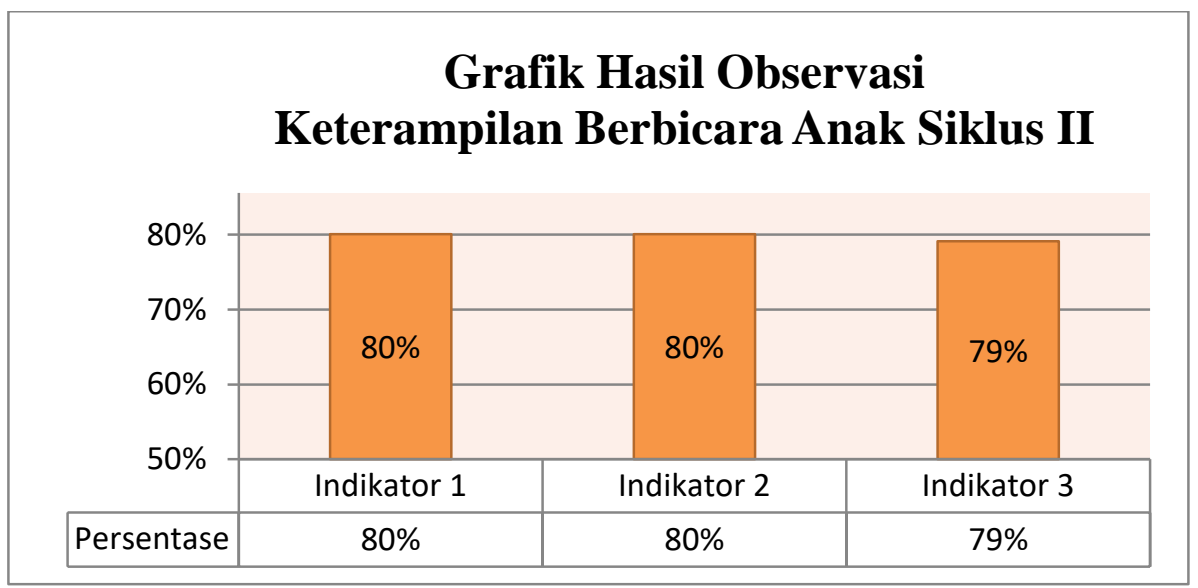

Gambar 2. Hasil Observasi Keterampilan Berbicara Anak Siklus II

Berdasarkan hasil observasi keterampilan berbicara anak pada Siklus II dapat diketahui bahwa hasil rata-rata penilaian keterampilan berbicara anak pada Siklus II sebesar $80 \%$. Hal ini berarti keterampilan berbicara pada anak kelompok B di TK Banyu Urip telah meningkat dan telah mencapai target. Peningkatan tersebut dapat dilihat dari sebelum tindakan (pratindakan), kemudian adanya tindakan kelas Siklus I dan Siklus II, dengan persentase rata-rata keterampilan berbicara yang semula sebelum tindakan (pratindakan) yaitu sebesar 56\%, meningkat menjadi 67\%, kemudian meningkat kembali menjadi $80 \%$. Sehingga dapat disimpulkan bahwa keterampilan berbicara anak dapat ditingkatkan melalui kegiatan bercerita dengan menggunakan media boneka kaus kaki.

\section{Refleksi}

Dalam refleksi ini dibahas mengenai data yang diperoleh pada pelaksanaan Siklus II. Anak begitu antusias mengikuti pembelajaran karena pembelajaran dari guru membuat anak senang dan tertarik mengikutinya, sehingga anak tidak ramai sendiri. Anak juga antusias saat diminta untuk maju ke depan untuk menceritakan kembali isi cerita yang baru saja dibawakan. Hal ini terbukti saat guru meminta anak untuk menceritakan kembali, guru tidak perlu menunjuk siapa yang maju tetapi anak sudah berlomba-lomba untuk maju. Selain itu anak lebih percaya diri dan termotivasi untuk menceritakan kembali isi cerita dengan baik karena adanya penghargaan berupa coklat sebagai apresiasi dari guru.

Pada Siklus II keterampilan berbicara pada anak Kelompok B sudah mengalami peningkatan lebih dari $75 \%$ dengan indikator Berbicara lancar dengan kalimat sederhana dan dipahami orang lain, menjawab pertanyaan (apa, siapa, mengapa, dimana, kapan dan seterusnya), menceritakan kembali cerita dengan lancar. 
J-SANAK: Jurnal Kajian Anak

(p-ISSN: 2686-5343 le-ISSN: 2715-7989)

Vol. (2)(02), (Januari-Juni)(2021), (Halaman)(60-75)

DOI: https://doi.org/10.24127/j-sanak.v2i02.817

Keterampilan bicara anak telah mengalami peningkatan dan telah memenuhi kriteria sangat baik pada indikator keberhasilan penelitian yaitu mencapai $>75 \%$, hal ini berarti telah memenuhi indikator keberhasilan, sehingga penelitian dirasa cukup dan dihentikan sampai Siklus II.

\section{Pembahasan}

Penelitian ini bertujuan untuk mengetahui apakah metode bercerita dengan menggunakan media boneka kaus kaki dapat peningkatan keterampilan berbicara pada anak kelompok B di TK Banyu Urip. Untuk mengetahui tingkat keefektifan metode bercerita menggunakan media boneka kaus kaki maka penelitian ini perlu dilakukan beberapa tahapan. Tahapan tersebut dalam penelitian ini ada tiga yaitu penilaian Pra Tindakan, Siklus I, dan Siklus II.

Dari hasil penelitian dapat dilihat bahwa terdapat peningkatan keterampilan berbicara pada anak setelah diberi perlakuan bercerita menggunakan media boneka kaus kaki. Hal ini terlihat ada peningkatan dari sebelum adanya tindakan dengan persentase rata-rata nilai anak 56\% menjadi 67\% setelah dilakukan tahapan Siklus I, dan Siklus II mengalami peningkatan menjadi $80 \%$.

Namun pada TK Banyu Urip ketika guru mebacakan cerita tanpa menggunakan media anak-anak merasa kurang tertarik dengan apa yang diceritakan oleh guru. Berbeda ketika guru menggunakan media pembelajaran berupa boneka kaus kaki, maka anak-anak mulai antusias mendengarkan cerita. Sejalan dengan yang disampaikan oleh Eliyawati Cucu (2005) Bahwa rasa ingin tahu dan antusias yang besar terhadap suatu hal yang baru dilihat oleh anak kan lebih memperhatikan dengan serius apabila media yang digunakan oleh guru menarik dan baru dilihat oleh anak.

Hal ini dapat ditemui ketika pada tahapan pra tindakan ketika guru membacakan cerita anak-anak ada yang masih ramai, dan jahil terhadap teman lainnya, berbeda dengan Siklus I dan Siklus II yang anak-anak mulai antusias untuk mendengarkan cerita. Dengan menggunakan media boneka kaus kaki anak-anak kelompok B di TK Banyu Urip terlihat sangat anatusias. Sejalan dengan yang disampaikan (Sandra, 2012) menggunakan media boneka kaus kaki dalam bercerita akan melibatkan panca indra secara bersamaan sehingga pembelajaran akan lebih bermakna dengan nilai-nilai yang ingin disampaikan mudah untuk diterima.

Dengan meningkatnya perhatian anak terhadap yang diceritakan guru maka akan ada peningkatan keterampilan berbicara pada anak. Hal ini dapat dibuktikan dengan adanya peningkatan rata-rata nilai keterampilan berbicara anak kelompok B di TK Banyu Urip pada setiap tindakan kelas, pada Pra-tindakan memeroleh nilai rata-rata 56\% mengalami peningkatan pada siklus I menjadi 67\% dan mengalami

Copyright ( 9 2020, Universitas Muhammadiyah Metro| 73 
J-SANAK: Jurnal Kajian Anak

(p-ISSN: 2686-5343 e-ISSN: 2715-7989)

Vol. (2)(02), (Januari-Juni)(2021), (Halaman)(60-75)

DOI: https://doi.org/10.24127/j-sanak.v2i02.817

peningkatan pada siklus II menjadi $80 \%$. Dengan demikian dapat dikatakan bahwa melalui metode bercerita dengan menggunakan media boneka kaus kaki, dapat mengembangkan keterampilan berbicara anak.

\section{KESIMPULAN}

Berdasarkan hasil penelitian yang dilakukan oleh peneneliti melalui penelitian tindakan kelas selama dua siklus, maka dapat disimpulkan bahwa penggunaan metode bercerita dengan media boneka kaus kaki mampu peningkatan keterampilan berbicara pada anak kelompok B di TK Banyu Urip, Kecamatan Sawahan, Kota Surabaya.

Keterampilan berbicara anak kelempok B melalui metode bercerita dengan menggunakan media boneka kaus kaki merupakan upaya yang dilakukan oleh pendidik untuk peningkatan proses kegiatan pembelajaran dengan tidak hanya berpusat pada guru (teacher centered). Melainkan memberikan kesempatan berbicara untuk setiap anak dengan begitu menjadikan anak lebih terampil berbicara.

Peningkatan keterampilan berbicara anak melalui metode bercerita dengan menggunakan media boneka kaus kaki dapat dibuktikan dengan peningkatan persentase nilai rata-rata keterampilan berbicara dari sebelum dilakukan tindakan (pratindakan) hingga dilakukannya tindakan kelas pada Siklus I dan Siklus II. Pada Pra Tindakan atau sebelum dilakukan tindakan kelas menunjukkan bahwa keterampilan berbicara anak masih dalam kondisi minim atau belum berkembang secara maksimal dengan persentase rata-rata sebesar 56\%, yang kemudian setelah dilakukan tindakan kelas mengalami peningkatan sebesar $11 \%$ pada Siklus I sehingga menjadi 67\%. Pada Siklus I tersebut keterampilan berbicara belum meningkat sesuai target, maka dilaksanakan kembali tindakan kelas yaitu Siklus II yang kemudian berhasil meningkat $>75 \%$ atau lebih dari target yang telah ditentukan yaitu rata-rata pada Siklus II sebesar $80 \%$, hal ini berarti telah memenuhi indikator keberhasilan..

\section{E. DAFTAR PUSTAKA}

Arikunto, Suharsimi. 2010. Penelitian Tindakan Kelas. Jakarta: Bumi Aksara.

Daryanto. 2013. Media Pembelajaran. Yogyakarta: Gava Media

Eliyawati Cucu. 2005. Pemilihan dan Pengembangan Sumber Belajar Untuk Anak

Usia Dini. Jakarta : Depdiknas

Moeslichatoen R. 2004. Metode Pengajaran di Taman Kanak-kanak. Jakarta: Rineka Cipta.

Sandra. 2012. "Penerapan Media Boneka Kaus kaki Untuk Meningkatkan Kemampuan Berbicara Anak Usia 5 - 6 Tahun Di Tk Melati / Aba 005 Pulau 
J-SANAK: Jurnal Kajian Anak

(p-ISSN: 2686-5343 e-ISSN: 2715-7989)

Vol. (2)(02), (Januari-Juni)(2021), (Halaman)(60-75)

DOI: https://doi.org/10.24127/j-sanak.v2i02.817

Balai." Jurnal Primary Program Studi Pendidikan Guru Sekolah Dasar Fakultas Keguruan dan Ilmu Pendidikan Universitas Riau. Vol 1(2).

Yoni, Acep. 2010. Menyusun Penelitian Tindakan Kelas. Yogyakarta: Familia. 